\title{
Effect of Teaching Program on Nurs's Performance Regarding Bone Marrow Transplantation
}

Asmaa Abd Elrahim Ali ${ }^{1}$, Mogedda Mohmed ${ }^{2}$, Doaa Mohamed Sayed ${ }^{3} \&$ Naglaa Ahmed Ahmed ${ }^{4}$.

1. B.Sc. Nursing, Faculty of Nursing, South Egypt Cancer Institute, Assiut University, Assiut, Egypt.

2. Assistant Professor of Critical Care and Emergency Nursing Department Faculty of Nursing Assuit University, Egypt.

3. Professor of Clinical Pathology and Excutive Director of Bone Marrow Transplantation South Egypt Cancer Institute, Assiut University, Assiut, Egypt.

4. Lecturer of Critical Care and Emergency Nursing Department Faculty of Nursing Assuit University, Egypt.

\begin{abstract}
Background Bone marrow transplantation is an advanced therapeutic intervention that is required for a number of malignant and nonmalignant medical conditions, often for critically ill patients. the nurses needed to be provided with knowledge and practice to give high quality of care for patient. Aim of the study: was to evaluate The effect of teaching program on nurses performance regarding bone marrow transplantation. Study Design: Quasiexperimental pre-post test research design was utilized.. Setting The study was conducted in bone marrow transplantation unit and other critical care unit at south Egypt cancer institute at Assiut University hospital Sample: All nurses (30) from above mentioned setting. Tools: An interview questionnaire for the nurse, Tool 1 knowledge assessment tool will be utilized, Tool 2. Observational chicklist for practise assessment tool will be utilized Results nurses knowledge was significant improved from 18.47 ( to $\$ 32.77$ respectively and nurses practice was improved from 48.47 to 96.5 after the implementation of the program. Conclusion: There were highly significant improvement in knowledge and practice after implementation of program about bone marrow transplantation. Recommendation; Continues nursing education and training programs at critical care units should be organized within south Egypt cancer institute.
\end{abstract}

\section{Key words: Bone Marrow Transplantation, Teaching Programe \& Nurs's Performance.}

\section{Introduction}

Bone marrow transplantation (BMT) Now today a life-saving treatment for many incurable diseases. Over the last two decades,BMT has seen rapid expansion and a constant evolution in technology use( Daikeler, Hirano, 2009) hematopoietic stem cell transplantation (hsct) is the transplantation of multi potent hematopoietic stem cells, usually derived from bone marrow, peripheral blood, or umbilical cord blood (Felfy, et al., 2014)

largely, hematopoietic stem cell transplantation(hsct) can be divided into two types: (Felfy, 2014) autologous where a patient donates the marrow stem cells to himself, and (Park, 2015) a more elaborate and complex process of allogeneic (HSCT) where a patient receives the stem cell graft from a healthy person (Hashemi, 2015) hematopoietic stem cell transplantation remains a dangerous procedure with many possible complications; it is reserved for patients with life-threatening diseases. as survival following the procedure has increased, its use has expanded beyond cancer to autoimmune diseases and hereditary skeletal dysplasias; notably malignant infantile osteopetrosis (Hashemi, 2017)

Stem cell's transplant is a surviving procedure that can increase life expectancy of end-stage or chronically ill patients. The The first transplant of stem cells was conducted in the year 1968 in the United States and since then, there has been tremendous development in this technology related to scientific research and technological advances in the medical field (Mendes, 2013).

Nurses' basic functions regarding these patients includes; care to maintain life, specialized technical care, provide extensive teaching for patients and their families before discharge regarding; medications, chemotherapy, bone marrow transplant restrictions, lab values, catheter care and the importance of follow-up. They also assist, support, and provide consultations for other nurses in the health care field

(Diezn, et al., 2017)

Specialized nursing care, which is required to prevent and manage the expected and unexpected toxicities of( HSCT).Nursing staff in contact with HCT patients should routinely follow appropriate hand hygiene practice to avoid exposing patients to bacterial pathogenes infection prevention and heallth care facilities additional precaution for patients colonized with certain Contagious pathogenes e.g MRSA,VRE and for special sitiuation e.g diarrhea, respiratory disease and instruction with regard to visitores, and Plants are described in the infection prevention and control in health care 
facilities.\{Oliansk et al., 2007) (Colombo, et al., 2005).

Nurses should have professional and ethical responsibilities to make sure that their knowledge and skills regarding bone marrow transplantation are upto-date and they practice safely and competently at all times (Royal College of Nursing, 2012). Thus, education about infection prevention and control was targeted as one of the main objectives of the infection control programs especially where nurses represent the largest group of workers within the healthcare system (Rasslan, 2011 \& WHO, 2008)

\section{Significance of the study}

The use of bone marrow (BM) for healing purposes dates back long in history, and BM from hunted animals might have contributed as rich nourishment to the evolution of Homo sapiens (McCann, 2016). Its recognition as primary hematopoietic organ in adult life with ahematopoietic stem cell as source of the circulating blood cells began in the middle of the nineteenth century (Schinck, 1920 $\}$. The study will be conducted in bone marrow transplantation (BMT) unit of South Egypt Cancer institute at Assuit University for both adult and child only from three years so that the nurses needed to be provided with knowledge and practice to give high quality of care for patient. and to decrease post transplantation complications. The reported incidence of bone marrow transplantation patient in south Egypt cancer institute at 2016/2018 was about 15 patients.

\section{Aim of the study}

Evaluate the effect of teaching program on nurses' performance regarding bone marrow transplantation. Research hypothesis

Knowledge and practice scores of nurses regarding bone marrow transplantation will expected to be improved after implementation of teaching program .

\section{Sample \& Method \\ Researtch Design}

Quasi-experimental pre-post test research design will be utilize to fullfill the aim of this study.

\section{Setting}

The study was conducted in bone marrow transplantation (BMT) unit of South Egypt Cancer institute at Assuit University

\section{Sample}

All available nurses provided care for patients under going bone marrow transplantation unit and other internal medical oncology department The sample size was (30) nursing staff .

Tools of data collection: Two tools were used to collect the data for this study. These tools aimed to evaluate the effect of teaching program on nurses performance regarding bone marrow transplantation.

Tool I: -knowledge assessment tool: It was comprised of two parts:-

Part (A): Socio- Demographic characteristics of the nurses: which includes; nurses' code, age, gender, level of education, years of experiences, job description and previous training about care of patients undergoing bone marrow transplantation . it was included ten $(10)$ multiple choise question .

Part (B): Nurses' Knowledge Assessment Sheet: Structure Questionnaire :

This part will developed by the researchers after reviewing of the related literatures $\{\mathbf{L i m a}, \mathbf{\&}$

Bernardino, 2014) (Childs, 2011)

to assess nurses' knowledge before, and after implementation of teaching program regarding bone marrow transplantation. about definition, sourses of stem cells, types of donor, indication, complication , drugs, precaution, nursing care It was included the following:- general knowledge (Ten true or false questions, Fourteen multiple choise question and Three open ended question

Scoring system of nurses' knowledge: Two level of scoring for questions were as the following:

Correct answer scored one Don't' know or incorrect answer scored zero The total scoring system of nurses' knowledge was 34 . and it was categorized into two levels -Satisfactory of total score of knowded $\geq 60 \%$ of the total score .Unsatisfactory of total score $<60 \%$ of the total score .

Nurs's Knowledge level of critical care nurses regarding BMT

Tool II: Practice assessment observational chicklist: This tool was used before and after the implementation of the designed teaching program to evaluate the effect of the designed nursing care on nurses' practice. (Bhatia, \& Bhatia, 2011) (Goodwin, 2015)

this tool will be developed by researcher after review literature to asses skills level of critical care nurses regarding BMT. It consists of the following items

1-Performing hand washing .It was include Eleven steps.

2-Performing oral care. It was include Eleven steps.

3-Putting and removing sterial gloves. It was include

Threeten steps .

4-Dressing and removing gown. It was include Ten steps .

5-Performing care for catheter It was include Ten steps .

Scoring system for nurses' practice was as the following: -Done practices correctly scored fone point) or done practices incorrectly scored (zero). and it was categorized into two levels -Satisfactory 
of the total score $\geq 60 \%$ and Unsatisfactory of the total score $\leq 60 \%$

\section{Ethical approval}

An official authorization to conduct the study was obtained by the researcher from the Dean of the South Egypt Cancer Institute. Oral consent for voluntary participation was obtained from each nurse; and the nature and purpose of the study was described. The researcher emphasized that the participation is voluntary, confidentiality and anonymity of the subjects was assured through coding of all data.

\section{Method}

The study was conducted throughout three phases, which are preparatory phase, implementation phase and evaluation phase.

\section{Method of data collection}

An individual interview was used to collect data the time needed to complete the tool was 15 minutes (nurse knowledge questionnarsheet)

Every nurse was interviewed at break time to collect data, Data collection was carried out from "june 2018 until october 2018".

\section{- Observational checklist}

Every nurse was observed to collect data of observational check list, Observation checklist for nurses carried out during the morning and afternoon two days/ week, and the time of each session was about two hour.

\section{Technique for data collection}

The study was conducted throughout three main phases which include: preparatory phase, implementation phase and evaluation phase

\section{Preparatory phase}

permission to conduct the study was obtained from hospital responsible authorities after explanation of the aim of the study.Tthe data collection tool were developed by the researcher based on the reviewing relevant literature .The developed tool will be tested for content related validity by 5 experts in the field of critical care nursing and critical care medicine at Assuit university . Permission for voluntary paticipation was obtained from nurses and the nature and purpose of the study will be explained.

\section{A pilot study}

was conducted on (10\%) from nurses to test the feasibility and applicability of the tools and to determine any obstacles that may encountered during the period of data collection, accordingly, needed modification was done.

Content validity; By jury of 5 Experts in the field of critical care nursing and critical care medicine from south Egypt cancer institute, the tools was tested for content the validity and the necessary modification.

The reliability for the study tools was calculated by Cronbach's coefficient alpha, it was(knowledge assessment tool $=0.820$ and practice assessment tool $=0.733$ )

\section{Ethical consideration}

Research proposal was approved from ethical committee in the faculty of nursing. There is no risk for study subject during application of research. The study was follow common ethical principles in clinical research.written informed consent was obtained from responsible person after explaining the nature and the purpose of the study. Patient was assured that the data of this research will not be reused without second permission. Confidentiality and anonymity was assured. Patient has the right to refuse participation or withdraw from the study without any rational at any time.

\section{Implementation phase}

Assesment of knowledge was done twice as fowllows. One at the beginning of the study was consider as pretest assesment and as base line data for latter comparison with future post test. The second administration of questionnaire was carried out after implementation of the teaching program to identify its effect on nurses knowledge. Assess nurses skills .The researcher observes the nurse skills using observational chicklist tool befor and immediately after Implementation program.The researcher completes the check list while the nurses demonstrate nursing procedure related to BMT.

Development of the teaching program

The teaching program was developed by the researcher after reviewing the relevant literature Wheatley T 2017. an illustrative structured booklet was prepared and written in simple Arabic language supported by illustrative pictures as a guide for the nurses, and different methods were used as video, group discussion and power point for theoretical part and demonstration and re-demonstration for the practical part. A booklet was given to each nurse during sessions to refresh their knowledge. The educational guideline was conducted in (4) sessions (two sessions for theoretical knowledge and two sessions for practical demonstration) to all nurses who are divided to (6) groups; each group was contained 5 nurses, two days/ week, and the time of each session was about two hour. Objectives of the study were prepared based on the aim and needs of the study subjects.

\section{Theoretical part include}

Definition, sourses of stem cells, types of donor ,indication ,complication, drugs and precaution for infection control, nursing performance include; nursing care of patient in bone marrow transplantation unit such as care for catheter, care for skin ,care for mouth and care after discharge. 


\section{Evaluation phase}

Knowledge and practice of each nurse was evaluated twice befor and after implementation program by using tool 1 and tool 2 and was determine the scoring system for observational check list `knowledge and practice were classified as: Satisfactory $\geq 60 \%$ UN satisfactory $\leq 60 \%$ to evaluate the Effect of teaching program on gaining nurses knowledge and practice regarding bone marrow transplantation.
Statistical analysis

An appropriate statistical method and tests were used for analysis of data by using SPSS, All data were collected, coded, tabulated and subjected to statistical analysis. Statistical analysis is performed by statistical Package SPSS in general, also Microsoft office Excel is used for data handling and graphical presentation.

\section{Result}

Table (1): percentage, distribution of socio demographic data of studied nurses $\{$ no $=30 \%$.

\begin{tabular}{|c|c|c|}
\hline ITEMS & No. $(n=30)$ & $\%$ \\
\hline \multicolumn{3}{|l|}{ Gender } \\
\hline Male & 3 & 10.0 \\
\hline Female & 27 & 90.0 \\
\hline \multicolumn{3}{|l|}{ Age } \\
\hline $18<25$ year & 25 & 83.3 \\
\hline $25<45$ year & 3 & 10.0 \\
\hline $45<65$ year & 2 & 6.7 \\
\hline Mean +SD(range) & $26.97+7.67(18-48)$ & \\
\hline \multicolumn{3}{|l|}{ Educational Level } \\
\hline Medium education & 1 & 3.3 \\
\hline Technician institute & 7 & 23.3 \\
\hline Bachelor of Nursing & 22 & 73.3 \\
\hline \multicolumn{3}{|l|}{ Marital Status } \\
\hline Single & 10 & 33.3 \\
\hline Married & 19 & 63.3 \\
\hline Widow & 1 & 3.3 \\
\hline \multicolumn{3}{|l|}{ Years of experience } \\
\hline Less than one year & 2 & 6.7 \\
\hline 1 year to $<5$ year & 18 & 60.0 \\
\hline More than 5 year & 10 & 33.3 \\
\hline \multicolumn{3}{|c|}{ Attendance of previouseTraining courses about bone marrow transplantation } \\
\hline Yes & 8 & 26.7 \\
\hline No & 22 & 73.3 \\
\hline
\end{tabular}

Table (2): Mean nurs`s knowledgd about bone marrow trans plantation through out study phases.

\begin{tabular}{|l|c|c|c|c|}
\hline \multicolumn{1}{|c|}{ Program items } & $\begin{array}{c}\text { Max } \\
\text { score }\end{array}$ & $\begin{array}{c}\text { Before } \\
\text { education }\end{array}$ & $\begin{array}{c}\text { After } \\
\text { education }\end{array}$ & P.value \\
\hline Anatomy and physiology of bone marrow & 6 & $2.8 \pm 1.13$ & $5.87 \pm 0.35$ & $<0.001^{* *}$ \\
\hline Importance and sources of stem cells & 4 & $3.07 \pm 0.87$ & $3.83 \pm 0.38$ & $<0.001^{* *}$ \\
\hline Definition of bone marrow trans plantation & 3 & $1.57 \pm 1.01$ & $2.97 \pm 0.18$ & $<0.001^{* *}$ \\
\hline Indication of bone marrow transplantation & 2 & $1.53 \pm 0.68$ & $2 \pm 0$ & $<0.001^{* *}$ \\
\hline Types of bone marrow transplantion & 5 & $1.57 \pm 1.19$ & $4.93 \pm 0.25$ & $<0.001^{* *}$ \\
\hline Nursing Management & 12 & $7.23 \pm 1.92$ & $11.33 \pm 1.42$ & $<0.001^{* *}$ \\
\hline Complication from bone marrow transplantation & 2 & $1.13 \pm 0.43$ & $1.83 \pm 0.38$ & $<0.001^{* *}$ \\
\hline Knowledge Score & 34 & $18.47 \pm 4.64$ & $32.77 \pm 2.36$ & $<0.001^{* *}$ \\
\hline
\end{tabular}

- independent t-test $* *$ Significant difference at p. value $<0.01$ 


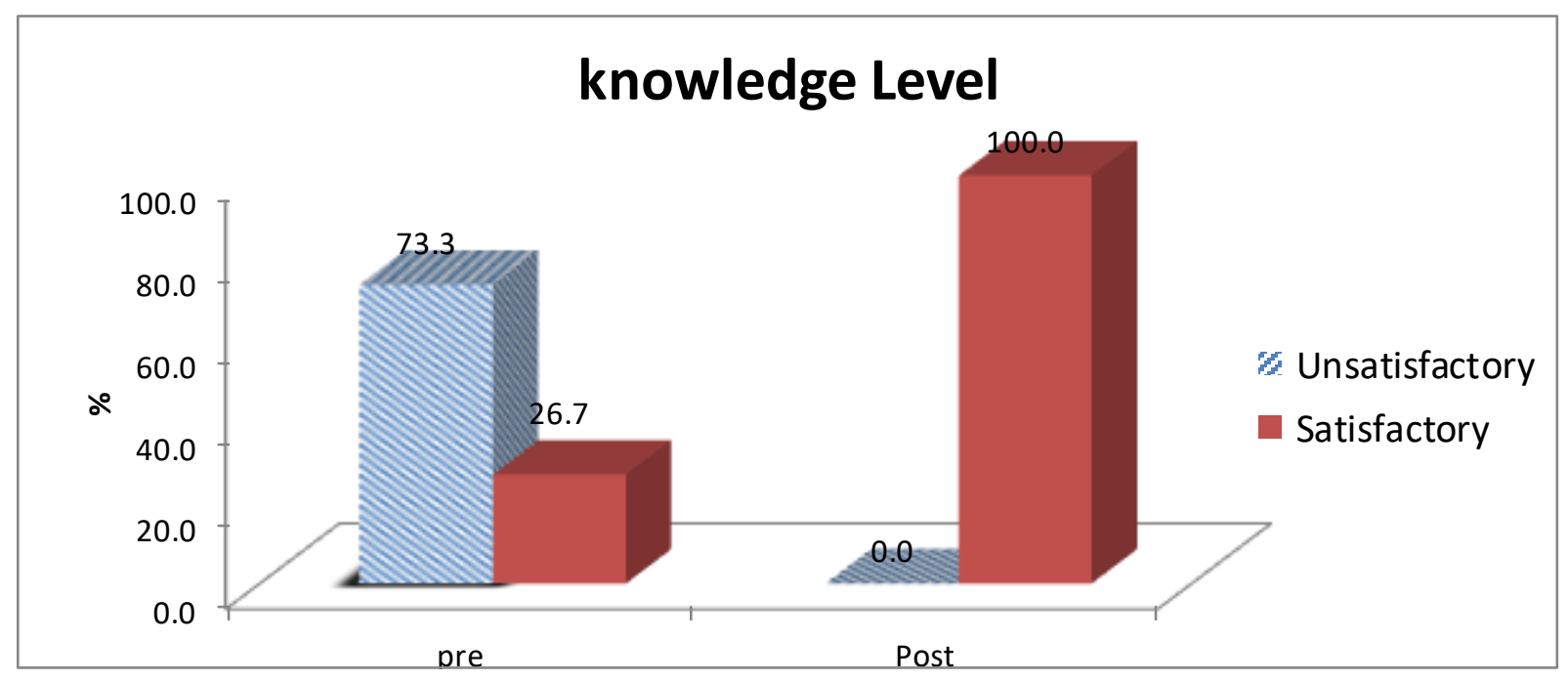

Figure $(1)$ percentage, distribution of nurses knowledge about bone marrow transplantation Throughout the study phases

Table(3): Mean Nurs`S Practice Before And After Program implementation About BMT.

\begin{tabular}{|l|l|l|l|l|l|}
\hline \multicolumn{1}{|c|}{ Program Items } & \multicolumn{1}{c|}{ Score } & \multicolumn{1}{c|}{ Pre } & \multicolumn{1}{c|}{ post } & \multicolumn{1}{c|}{ T } & P. value \\
\hline hand washing & 22 & $8.2 \pm 1.13$ & $17.67 \pm 0.66$ & -39.701 & $<0.001^{* *}$ \\
\hline Gloving & 36 & $18.17 \pm 3.06$ & $32.13 \pm 2.46$ & -19.471 & $<0.001^{* *}$ \\
\hline Gowning & 18 & $9.73 \pm 0.45$ & $16.37 \pm 0.49$ & -54.616 & $<0.001^{* *}$ \\
\hline Oral Care & 38 & $12.37 \pm 1.27$ & $30.33 \pm 3.86$ & -24.198 & $<0.001^{* *}$ \\
\hline Total practice score & 114 & $48.47 \pm 3.29$ & $96.5 \pm 4.7$ & -45.895 & $<0.001^{* *}$ \\
\hline
\end{tabular}

- independent t-test $* *$ Significant difference at p. value $<0.01$

there is highly statistlical difference between nurs`s pre\&post practice according to degree with $p$ value0.001

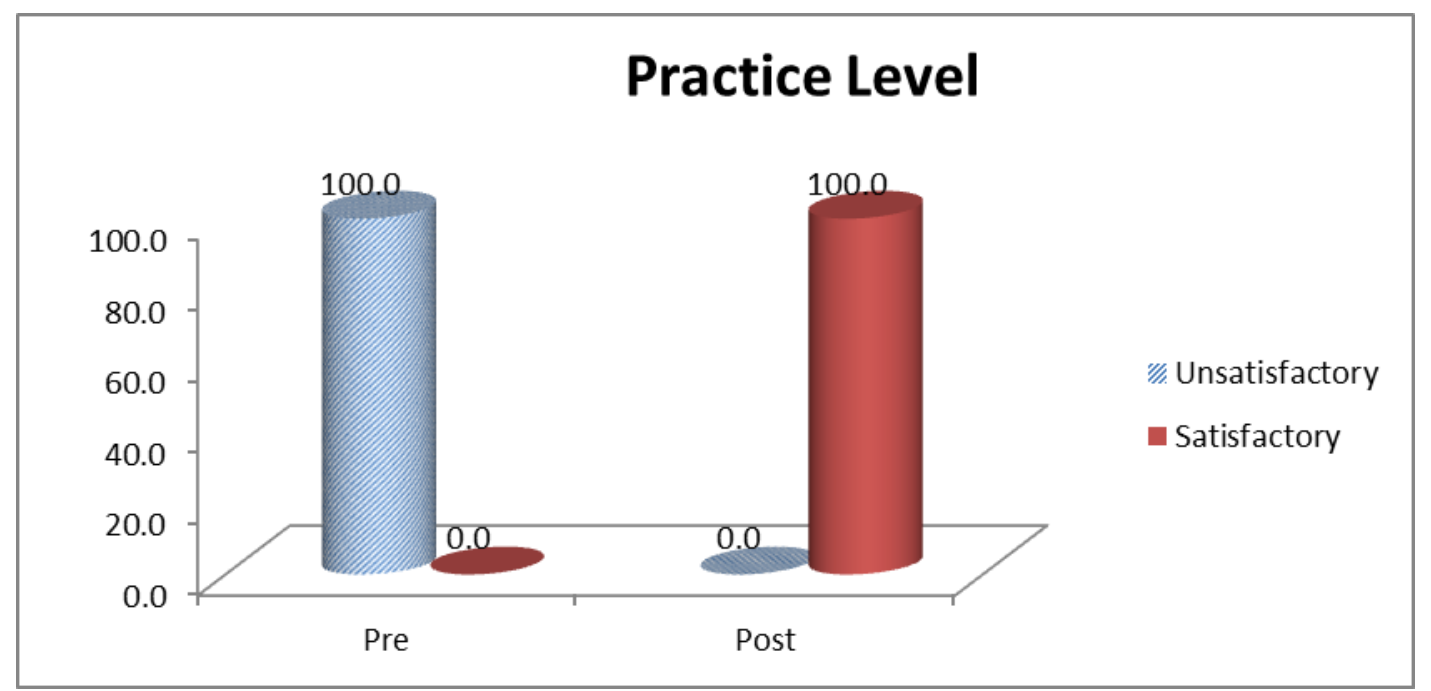

Figure (2): percentage, distribution of nurses practices Before And After Program about bone marrow transplantation 


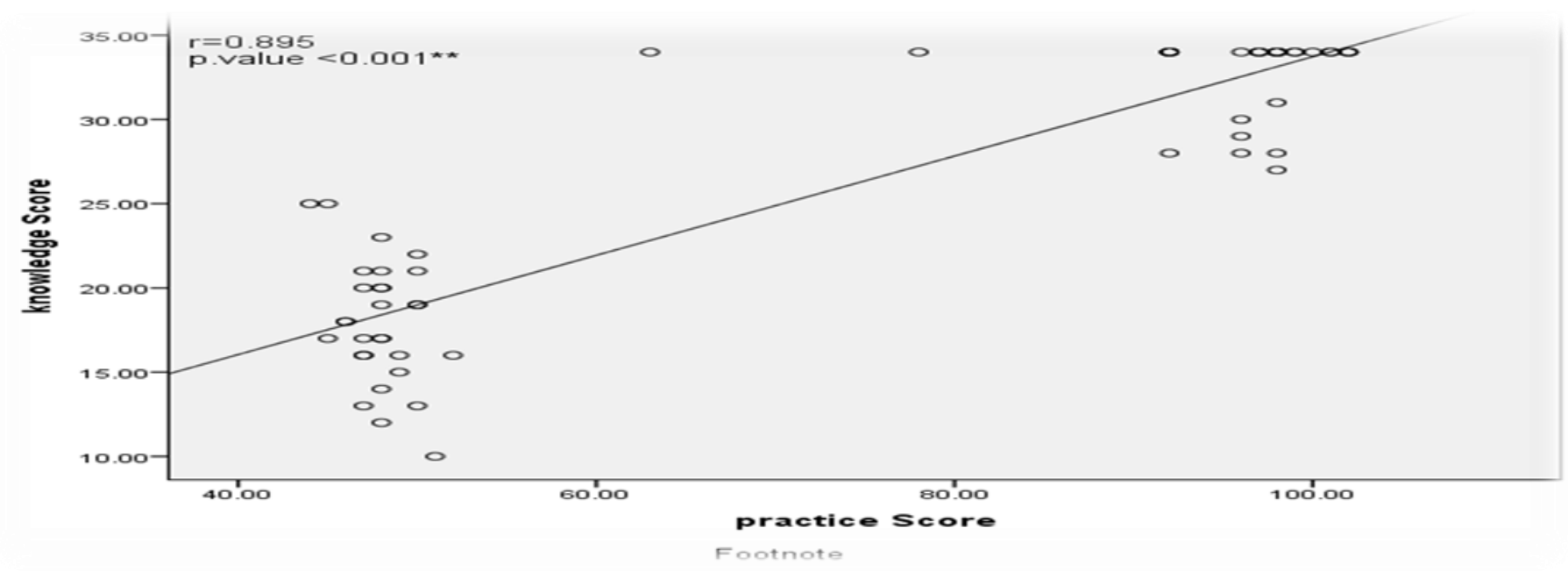

Figure (3): correlation co-efficient between knowledge and practice result.

Table (1): Show that most of nurses were female with percentage $90 \%$,more than half of them aged between 18 to $<25$ years and hade technician education level, marietal status are single with percentage $33.3 \%$ and married with percentage $63.3 \%$ and about $23 \%$ of group had 3 monthes of training course .most of group hadn`t training course about bone marrow transplantation $\{$ bmt] with percent $76.6 \%, 73,5 \%$ of group hadn`t previously worked at $($ bmt $)$ unit

Table (2): This table showed that there were improvement among nurses' knowledge regarding scoring from $18.47 \pm 4.64$ to $32.77 \pm 2.36$.So there was statistical significant difference between levels of nurses' knowledge befor and after implementation of program at $P$ value $<0.01$

Table (3): This table show that there is highly statistlical significant difference between nurs`s practice befor and after program about bone marrow transplantation according to degree with $\mathrm{p}$ value 0.001 Figure (1): Show that knowledge level improved after implementing teaching program and show that level of satisfaction befor program was 26.7and improved to $100 \%$ post program implementation .

Figure (2): Show that practice was un satisfactory befor teaching program and became satisfactory after implementing teaching program

Figure (3): Show that there was positive correlation between knowledge and practise

\section{Discussion}

Bone marrow transplantation is a medical procedure in which healthy stem cells are used to replenish the defective bone marrow of those with malignant and non-malignant diseases (Niess, 2013) The nurses are dedicated for promoting quality of life and providingan optimal physical and emotional comfort (Diez, et al., 2017):

The aim of this study was to evaluate effect of teaching program on nurses performance regarding to bone marrow transplantation.

The study result revealed that more than half of the nurses were in the age group $(18>25)$ years old. It may be due to the unit was recently established and the administrators selected young age nurses to be able to perform mainly tasks in the unit effectively.

This result was in the same line with Mohamed \& Sayed (2015) who reported in their study about nurses' knowledge regarding stem cells therapy that more than half of nurses were aged from 20-25 years.

Regarding educational level, the result showed that majority of nurses were bachelor degree, this result in not congruent with Mohamed \& Sayed (2015) who reported majority of nurses who are working in BMT unit had diploma degree in nursing. In relation to attending any previous training program, the majority of nurses had no previous training about BMT. This result was supported by Tork et al., (2018) mentioned that in their study participants from nurses had never attended training courses on stem cells therapy.

Regarding to nurses' knowledge there were significant improvement regarding total levels of nurses' knowledge about bone marrow transplantation befor and after implementation of teaching program. Low level of nurses' knowledge before implementation of teaching program may be attributed to the fact that bone marrow transplantation and stem cells are new advanced trend. Moreover, nursing curricula remained deficient in this issue 
which affects level of nurses' knowledge.the present study also revealed that there were a highly statistical significant difference befor and after implementation of educational program with $\{\mathrm{p}$ value 0.001$\}$ that may be educational program success in improving and updating nursing knowledge .In addition to Khalil \& Sharshor (2016) that assessed the nurses' knowledge about stem cells in Tanta, Egypt, they reported that nurses' knowledge about stem cells is inadequate in $69 \%$ of participants, so they need educational program to improve it. Elizebeth (2005) concluded that $84 \%$ of health professionals' team had inadequate knowledge about bone marrow and stem cell therapy. Therefore, it is necessary to update health professionals on latest trends \& developments in their knowledge.

Also Lai et al., (2016) who indicated that although there was a high level of awareness towards stem cells transplantation among medical students, but there was a poor level of general knowledge about stem cell. According to Moustafa \& Youness (2015) who reported that most maternity nurses had a low knowledge levels of stem cells and its uses. Also Tin tu (2007) revealed that during pre-test $40 \%$ from nurses had inadequate knowledge regarding bone marrow and stem cell therapy. After intervention showed that $80 \%(\mathrm{p}<0.05)$ was gained knowledge.

\section{Practice assessment of the studied nurses}

Regarding to nurses' practice about management of patients' pre, during and after bone marrow transplantation. The results showed that there were highly significant improvements in the nurses' practice regarding management of patients undergoing bone marrow transplantation. Also there was significant improvement in nurses' practice after transplantation regarding; hand washing, gloving, gowning and oral care and care for catheter when dealing with patient, after intervention of the teaching program. The lack of nurses' practice regarding bone marrow and stem cells transplantation may be due to late exposure to stem cell technology in the clinical environment as it was a later development and the bone marrow transplantation (BMT) unit of South Egypt Cancer institute at Assuit University is anew unite. Moreover the nurses lack the efficiency of updating their practice after being settled in the clinical environment for a longer time.

This result was in the line with, Holmes (1990) mentioned that nurses are an integral member of the multidisciplinary team who are caring for the bone marrow transplantation patient. The pre-transplant period is an intensive for the delivery of the preparative therapy, management of early complications, and teaching and support to the patient and family.
The study results revealed that there was significant improvement in nurses' practice regarding management of patients with bone marrow transplantation after application of the teaching program. This result was in the line with Kirsch et al., (2014) who reported that educational interventions are considered most effective for stem cell transplantation nurses regarding for training patients during their inpatient stay and providing patient/family teaching guidelines.

In the other hand Wheatley (2017) found that; guideline recommendations for routine preventive care are not always followed.

Mahmoud, (2004) reported that teaching programs for nursing staff constitutes an important part. These programs are urgently designed to assist staff nurses in developing and enhancing their skills needed to provide high standards of care to their patients. This agreed with the present study as nurse's knowledge and practice improved after implementation of the nursing intervention protocol.

Youssef, (2007) in the same line with the current study findings conducted a study at the reconstructive microsurgical and grammatology care units in Assiut University Hospital. Entitled "Micro vascular free tissue transfer surgeries, Impact of a designed teaching protocol on nurses' knowledge, practices and patient's outcome" which revealed that an improvement in nurses' practice after the attendance at continuing nursing education sessions.

Figueredo, (2009) showed in his study that bachelor educated RN were significantly better patient outcomes, that not in same line with the present study results. The educational level, years of experience, and age of studied nurses could be factors affecting on level of nurse's knowledge. This mean that those factors alone cannot affected on the level of nurse's knowledge.

Also the study result revealed that there was statistical significant positive correlation among nurses' knowledge and their practice level. This finding is in concordance with Ali, (2010) who indicated that there were highly significance differences through phases of study regarding knowledge and practice of universal precaution $(\mathrm{P}=0.0001)$ among studied nurses, there was statistically significant positive correlation was found between knowledge and practice Eskander, Morsy, \& Elfeky, (2013) they revealed statistically significant positive correlation between knowledge and practice of universal precautions. .and show that with improving knowledge the nurses practice improve.

On other hand Gijare, (2012) who reported similar results regarding correlation between knowledge and practice, there was no correlation between knowledge 
and practice. As well Askarian, McLaws, \& Meylan, (2007) who found that there was no correlation between knowledge and practice. Also Najeeb \& Taneepanichsakul, (2008) who reported a weak, negative relationship between knowledge and practice regarding infection control among doctors and nurses.

\section{Conclusion}

In the light of the current study, it can be concluded that: There were statistical significant improvements of nurses' knowledge and practice regarding Bone Marrow Transplantation post educational program than pre intervention period.

\section{Recommendations}

1. Based on the result of present study, following recommendations were made. Standards for nursing care of patients undergoing bone marrow transplantation should be established that contain update knowledge and practice .

2. Continued nursing education and in service training programs about bone marrow transplantation should be organized within south Egypt cancer institute.

3. Nurses should add to their routine obligations the regular reading of up to date references (periodicals, textbooks, etc.). They should always be encouraged to attend scientific meetings and conferences .

4. Nurses should be aware of complications, how to prevent it and how to deal with it when develop .

Limitations of the study: For the findings presented in this paper some limitations should be taken into account. Small sample size represents a limitation that could affect generalization of results

\section{Reference}

1. Ali, M., (2010): Assessment of nurses' knowledge and performance related to universal infection control precaution at mallaway general hospital depatrments, Faculty of Nursing , Assiut University, P.P. 80

2. Askarian, M., McLaws, M., \& Meylan, M., (2007): Knowledge, attitude, and practices related to standard precautions of surgeons and physicians in universityaffiliated hospitals of Shiraz, Iran. International journal of infectious diseases, 11(3), 213-219.

3. Diez N., Benware K., \& Dolan K., (2017): Hematology/Oncology Bone Marrow Transplant, and Stem Cell Transplant Programs, University Hospital Nursing, available on http:// www. upstate. edu/ nursing / down town/hemonc.php, All contents copyright , Upstate Medical University, P.P. 345- 348.
4. Eskander, H., Morsy, W., \& Elfeky, H., (2013): Intensive Care Nurses' Knowledge \& Practices Regarding Infection Control Standard Precautions at a Selected Egyptian Cancer Hospital. Journal of Education and Practice, 4(19), 160-174

5. Farsi, Z., Dehghan Nayeri, N., \& Negarandeh, R., (2010): Coping strategies of adults with leukemia undergoing hematopoietic stem cell transplantation in Iran: a qualitative study. Nursing \& health sciences, 12(4), 485492.

6. Figueredo V., (2009): the time has come physicians to takw notice, the impact of psycholsocial stressors on the heat, Americian journal of medicine, 122(8): P.P. 704: 712

7. Gijare, M., (2012): Effectiveness of teaching on infection control practices among health care professionals. Sinhgad e Journal of Nursing, 2(2), 5-9

8. Holmes W., (1990): Preparing the Patient for Bone Marrow Transplantation: Nursing Care Issues, the Yale Journal of Biology and Medicine,; 63:487, 488, 494.

9. Khalil, A., \& Sharshor S., (2016): Pediatric Nurses Knowledge, Awareness and Attitude towards Application of Stem Cells Therapy in Children, IOSR Journal of Nursing and Health Science, 5( 4): 88-96.

10. Kirsch M., Johansson E., Calza S., Eeltink C., Stringer J., Liptrott S., \& De geest S., (2014): Nurses' Practice Patterns in Relation to Adherence-Enhancing Interventions in Stem Cell Transplant Care: A survey from the Nurses Group of the European Group for Blood and Marrow Transplantation, European journal of cancer care, 23: 607-615.

11. Lai D., Ramasamy T., \& Amini F., (2016): knowledge, Awareness and Perception of Stem Cells Research amongst Malaysian Medical Students, Regenerative Research.; 4(2): 25-30

12. Mahmoud A., (2004): Nursing role toward patients undergoing abdominal laparoscopic surgery; a suggested training program. in MSN Assiut University,result, P.P.45.

13. Marquis L., \& Huston J., ( 2009): Leader ship roles and management functions in nursing, 6th ed., Lippincott, Hong Kong, pp. 371,

14. Moustafa M., \& Youness E., (2015): Nurses' knowledge about Umbilical Cord BloodBanking and its Barriers. IOSR J. Nurs. Health Sci., 4(2):44-53.

15. Najeeb, N., \& Taneepanichsakul, S., (2008). Knowledge, attitude, and practice of standard and transmission-based precautions of doctors and nurses in tertiary and secondary health care 
settings of Maldives. Journal of Health Research, 22, 45-48.

16. Niess, D., (2013): Basic concepts of transplantation, Hematopoietic Stem Cell Transplantation: A manual for Nursing Practice In S.A. Ezzone (Eds.), Pittsburgh, PA: Oncology Nursing Society, P.P 13- 25.

17. Mohammed H., \& EL Sayed H., (2015): Knowledge and Attitude of Maternity Nurses Regarding Cord Blood Collection and Stem Cells: An Educational Intervention. Journal of Nursing Education and Practice, 5(4): 58-69.

18. Schmajuk, M., DeGuzman, E., \& Allen, N., (2019): Psychotherapy in Transplant Patients. In Psychosocial Care of End-Stage Organ Disease and Transplant Patients (pp. 471-481). Springer, Cham.

19. Sullivan, K., Dykewicz, C., Longworth, D., Boeckh, M., Baden, L., Rubin, R., \& Sepkowitz, K., (2001): Preventing opportunistic infections after hematopoietic stem cell transplantation: the Centers for Disease Control and Prevention, Infectious Diseases Society of America, and American Society for Blood and Marrow Transplantation Practice Guidelines and beyond. ASH Education Program Book, 2001(1), 392-421.

20. Tintu P., (2007): Study to Assess the Effectiveness of Computer Assisted Education Programme Regarding Stem Cell Therapy among Staff Nurse. Rajiv gandhi university of health sciences karnataka, bangalore, M.sc (N).P.p. 22.

21. Tork H., Alraffaa S., Almutairi K., Alshammari N., Alharbi A., \& Alonzi A., (2018): Stem Cells: Knowledge and Attitude among Health Care Providers in Qassim region, KSA, International Journal of Advanced Nursing Studies, 7 (1): 1-7.

22. Youssef S., (2007): Microvascular free tissue transfer surgeries, Impact of a designed teaching protocol on nurse's knowledge, practices and patient's outcome. Submitted for fulfillment of the requirements of Doctorate Degree in Adult Nursing, Faculty of Nursing, Assiut University.

23. Felfly, H., Haddad, G., (2014): "Hematopoietic stem cells: potential new applications for translational medicine". Journal of Stem Cells. 9 (3): 163-97. PMID 25157450

24. Park, B., Yoo, K., Kim, C., (December 2015): "Hematopoietic stem cell expansion and generation: the ways to make a breakthrough". Blood Research. 50 (4): 194-203. doi:10.5045/br.2015.50.4.194. PMC 4705045. PMID 26770947
25. Hashemi Taheri A., Radmard A., Kooraki S., Behfar M., Pak N., Hamidieh A., Ghavamzadeh A., (September 2015): "Radiologic resolution of malignant infantile osteopetrosis skeletal changes following hematopoietic stem cell transplantation". Pediatric Blood \& Cancer. 62 (9): 1645-49. doi:10.1002/pbc.25524. PMID 25820806

26. Mendez-Ferrer S., Frenette P., Mesenchymal \& Haematopoietic Stem Cells Form A., Unique Bone Marrow Niche. Nature.(2010): 466:829-834. doi: 10.1038/nature09262. [PMC free article] [PubMed] .

27. Evidence scan Quality improvement training for health care professionals (2012): prepared by the Evidence Center on behalf of the Health Foundation Health Foundation)

28. Colombo, A., Solberg, B., Vanderhoeft, E., Ramsay, G., \& Schouten, H., (2005). Measurement of nursing care time of specific interventions on a hematology-oncology unit related to diagnostic categories. Cancer Nursing, 28(6), 476-480.

29. Oliansk DM-Rizzo J., Aplan P., (2007):The role of cytotoxic Therapy of acute Myeloid leukemia in children; an evidence -based review Biol Blood Marrow transplant 2007;13;125(pub med)

30. Mendes K., Roza B., Barbosa S., Schirmer J., Galv.o C., (2012): Transplante de .rg.os e tecidos: responsabilidades do enfermeiro. Texto Contexto Enferm.\{2012 Out-Dez; 21(4):945-53 [acesso 2013 Out 10].

31. McCann S., (2016): A history of haematology. From Herodotus to HIV. Oxford medical histories. London: OxfordUniversity Press

32. Royal College of Nursing (2012): Essential practice for infection prevention and control Guidance for nursing staff, London: RCN. Publication code: 004166.

33. Rasslan O., (2011): Infection Prevention and Control Education in Egypt: Professional Diploma in Infection Control(PDIC). Int J Infect Control 2011, v7:i2 doi:

34. World Health Organization (WHO): Hepatitis B. 2008. [Cited 15 Dec 2009.] Available from URL: http://www.who.int/mediacentre/ factsheets/fs204/en/ 10.3396.

35. Daikeler T., Hirano, Farge D., Andolina M., Gualandi F., Baldomero H., (2009): Allogeneic hematopoietic SCT for patients with autoimmune diseases. Bone Marrow Transplant. 2009;44(1):27-33. [PubMed]

36. Kirsch M., Johansson E., Calza S., Eeltink C., Stringer J., Liptrott S., \& Degeest S., 
(2014): Nurses' Practice Patterns in Relation to Adherence-Enhancing Interventions in Stem Cell Transplant Care: A survey from the Nurses Group of the European Group for Blood and Marrow Transplantation, European journal of cancer care, 2014, 23: 607-615

37. Moustafa M., \& Youness (2015): EM. Nurses' knowledge about Umbilical Cord BloodBanking and its Barriers. IOSR J. Nurs. Health Sci., 2015; 4(2):44-53

38. Wheatley T., (2017): Implementing and Evaluating a Nurse-Led Educational Intervention for Bone Marrow Transplant Patients in the Acute Care Setting, University of Kentucky College of Nursing, Spring 2017; 44

39. Elizebeth L., (2005): Study to Assess the Knowledge and Attitude of Various Health Professional Regarding Placental Stem Cell Therapy, Rajiv gandhi university of health sciences, karnataka, bangalore, M.c(N),2005; 33

40. Lima K., \& Bernardino E., (2014): Nursing Care in a Hematopoietic Stem Cells TransplantationUnit, Text Context Nursing, Florianópolis, 2014; 23(4): 845-53.

41. Bhatia S., \& Bhatia R., (2011): Transplantation-Related Malignancies, Cancer: Principles and Practice of Oncology, 9th ed. Philadelphia, Pa: Wolters Kluwer/Lippincott Williams \& Wilkins; 2011: 2113-2122.

42. Goodwin M., (2015): Nursing Care for a Client Receiving a Bone Marrow Transplant, 2015, Harvesting stem cells from the bone marrow. Available https://prezi.com/tgmt7dj3tlhr/nursing-care-fora-client-receiving-a-bone-marrow-transplant

43. Childs R., (2011): Allogeneic Stem Cell Transplantation. Cancer: Principles and Practice of Oncology. 9th ed. Philadelphia, Pa: Wolters Kluwer/Lippincott Williams \& Wilkins; 2011:2244-2261.

44. ADA Nutrition Care Manual, Academy of Nutrition \& Dietetics. (2012); The Fred Hutchinson Cancer Research Center has an example of a neutropenic nutrition therapy. Copyright 2012; The FDA Center for Food Safety \& Applied Nutrition 